\title{
KECEPATAN PEMBAKARAN PREMIXED CAMPURAN MINYAK JARAK - LIQUEFIED PETROLEUM GAS (LPG) PADA CIRCULAR TUBE BURNER
}

\author{
Defmit B. N. Riwu'1, I.N.G.Wardana², Lilis Yuliati ${ }^{3}$ \\ 1 Teknik Mesin Universitas Nusa Cendana Kupang, Adi Sucipto - Kupang (85361) - Indonesia \\ 2,3 TeknikMesin Universitas Brawijaya Indonesia, MT Haryono167 - Malang (65145) - Indonesia

\section{Abstract} \\ This study was conducted to determine the characteristics of premixed combustion of a \\ mixture of castor oil - LPG on a circular tube burner. Percentage of LPG fuel in a mixture of \\ jatropha curcas oil - LPG varied as much as $10 \%, 20 \%, 30 \%$, and $40 \%$ of the mass flow jatropha \\ curcas oil vapor. Considering the flame of fire there are two angles formed which describe burning \\ velocity. Also there are formed two cones of fire where the bright blue inside cone is a premixed \\ flame, while the outer blue white cone is flame a diffusion flame. An increase in the percentage \\ of $L P G$ makes the value of top and bottom angle increase. So that the burning velocity on the \\ upper angle decrease whilst on bottom angle increase.
}

\section{Keywords: Premixed combustion, equivalence ratio, LPG, jatropha curcas}

\section{PENDAHULUAN}

Pembakaran adalah teknologi tertua yang telah di pergunakan oleh manusia sejak manusia itu ada. Pada jaman sekarang ini, kehidupan manusia tidak bisa terlepas dari proses pembakaran, karena lebih dari $90 \%$ ketersediaan energi untuk keperluan manusia dihasilkan dari proses pembakaran [1]. Sebagai contoh digunakan untuk memasak, transportasi, listrik dan lain sebagainya. Proses pembakaran sendiri adalah suatu reaksi kimia antara bahan bakar dengan oksidator atau udara yang berlangsung secara cepat yang menghasilkan panas dan cahaya. Reaksi dapat berlanjut secara spontan melalui panas yang dihasilkan dari reaksi itu sendiri [2]. Pembakaran premixed adalah salah satu proses pembakaran dimana sebelum dibakar, bahan bakar dan udara di campur dalam suatu mixing chamber dengan cara mekanik. Aplikasi dari penggunaan pembakaran premixed seharihari terlihat pada penggunaan kompor dirumah tangga maupun pada industri, proses pembakaran pada S. I. Engine [3] dan lainnya.

Penelitian tentang pembakaran premixed telah banyak dilakukan dengan terbanyak menggunakan bahan bakar konvensional, sedangkan untuk bahan bakar minyak nabati telah dilakukan dengan beberapa bahan baku, seperti penggunaan minyak kelapa [4], minyak biji kapuk [5], dan minyak jarak pagar.

Dalam suatu proses pembakaran, kestabilan api sangat penting. Api dikatakan stabil apabila stasioner pada posisi tertentu dan terjadi pada saat kecepatan reaktan sama dengan kecepatan perambatan api. Kecepatan rambatan api terbesar terjadi pada $\Phi \approx 1$. Sedangkan pada campuran diluar itu, kecepatan api akan menjadi lebih rendah. Pada kondisi terlalu banyak udara berlebih juga akan mengakibatkan kehilangan panas dan efisiensi pembakaran berkurang. Equivalence ratio menunjukkan bahwa apakah dalam suatu proses pembakaran terjadi kelebihan udara atau campuran kelebihan bahan bakar. Equivalence ratio sangat berpengaruh terhadap kecepatan pembakaran[6].

Pencampuran uap minyak jarak pagar dan LPG bertujuan untuk menambahkan bahan bakar kedalam proses pembakaran agar supaya terjadi nyala api yang stabil pada pembakaran stoikiometri, dimana LPG ini berfungsi sebagai katalis dalam proses pembakaran ini, karena menurut Wardana (2008) kecepatan rambatan api tercepat pada pembakaran premixed LPG dicapai pada campuran sedikit lebih kaya yakni pada equivalence ratio sedikit diatas 1[7].

Dalam penelitian ini, minyak nabati terlebih dahulu diubah fasenya dari fase cair menjadi fase gas dengan cara mendidihkan minyak nabati tersebut, sehingga jarak antar molekul bahan bakar menjadi besar dan kemudian dicampur dengan molekul-molekul udara dan LPG di ruang bakar dan menjadi reaktan kemudian di berikan energi aktivasi 
sehingga dapat menghasilkan pembakaran premixed.

Debit uap minyak jarak pada penelitian ini ditentukan berdasarkan volume uap minyak jarak. Sehingga didapatkan massa jenis uap minyak jarak. maka massa alir uap minyak jarak bisa dihitung dengan menggunakan persamaan :

$$
\dot{m}=(\rho \times Q) \text { uap minyak }
$$

dimana $\rho$ adalah massa jenis dari uap minyak jarak dan $Q$ adalah debit uap minyak jarak.

Selanjutnya, untuk menghitung AFRactual dipergunakan maka dipergunakan persamaan berikut :

$$
A F R_{\text {aktual }}=\frac{\rho_{\text {udara }} \cdot Q_{\text {udara }}}{\rho_{\text {bahan bakar }} \cdot Q_{\text {bahan bakar }}}
$$

Dan untuk menghitung equivalence ratio dipergunakan rumus :

$$
\Phi=\frac{A F R_{\text {stoic }}}{A F R_{\text {aktual }}}
$$

Untuk perhitungan prosentase LPG yang ditambahkan dalam uap minyak jarak, didasarkan pada massa uap minyak jarak. Untuk menghitung kecepatan reaktan dipergunakan persamaan :

$$
V_{u}=\left(\frac{Q_{\text {udara }}+Q_{\text {bahan bakar }}}{A_{\text {nosel }}}\right)
$$

Untuk menghitung kecepatan pembakaran digunakan rumus :

$$
S_{L}=V_{u} \sin \alpha
$$

Dimana $V_{u}$ merupakan kecepatan reaktan dan $\alpha$ adalah sudut antara api dengan sumbu nosel.

\section{METODE PENELITIAN}

Skema instalasi penelitian ditunjukkan pada Gambar 1. Dalam penelitian ini menggunakan bahan bakar biodiesel minyak jarak dan LPG. Bahan bakar minyak jarak diproduksi oleh BALITAS Malang. Komposisi asam lemak dari minyak jarak dapat dilihat pada Tabel 1 yang peroleh berdasarkan hasil pengujian komposisi asam lemak minyak jarak di Laboratorium Penelitian Jurusan Farmasi UNAIR.

Tabel 1. Komposisi asam lemak dari minyak jarak dapat dilihat pada

\begin{tabular}{|l|l|l|}
\hline Asam lemak & $\begin{array}{l}\text { Rumus } \\
\text { kimia }\end{array}$ & $\begin{array}{l}\text { Prosentase } \\
\text { Massa (\%) }\end{array}$ \\
\hline Asam Miristat & $\mathrm{C}_{14} \mathrm{H}_{28} \mathrm{O}_{2}$ & 0,06 \\
\hline $\begin{array}{l}\text { Asam } \\
\text { 7-heksadekenoat }\end{array}$ & $\mathrm{C}_{16} \mathrm{H}_{30} \mathrm{O}_{2}$ & 0,04 \\
\hline Asam Palmitoleat & $\mathrm{C}_{16} \mathrm{H}_{30} \mathrm{O}_{2}$ & 0,75 \\
\hline Asam Palmitat & $\mathrm{C}_{16} \mathrm{H}_{32} \mathrm{O}_{2}$ & 16,04 \\
\hline $\begin{array}{l}\text { Asam } \\
\text { Heptadekanoat }\end{array}$ & $\mathrm{C}_{17} \mathrm{H}_{34} \mathrm{O}_{2}$ & 0,08 \\
\hline Asam Linoleat & $\mathrm{C}_{18} \mathrm{H}_{32} \mathrm{O}_{2}$ & 28,71 \\
\hline Asam Oleat & $\mathrm{C}_{18} \mathrm{H}_{34} \mathrm{O}_{2}$ & 43,8 \\
\hline $\begin{array}{l}\text { Asam } \\
\text { 7-oktadekenoat }\end{array}$ & $\mathrm{C}_{18} \mathrm{H}_{34} \mathrm{O}_{2}$ & 1,7 \\
\hline Asam Stearat & $\mathrm{C}_{18} \mathrm{H}_{36} \mathrm{O}_{2}$ & 8,64 \\
\hline Asam Eikosanoat & $\mathrm{C}_{20} \mathrm{H}_{40} \mathrm{O}_{2}$ & 0,18 \\
\hline
\end{tabular}

Berdasarkan tabel tersebut diatas maka reaksi pembakaran stoikiometri dari minyak jarak adalah sebagai berikut :

$0,0002631579 \mathrm{C}_{14} \mathrm{H}_{28} \mathrm{O}_{2}+0,0001574803$

$\mathrm{C}_{16} \mathrm{H}_{30} \mathrm{O}_{2}+0,0029527559 \mathrm{C}_{16} \mathrm{H}_{30} \mathrm{O}_{2}+$ $0,0626562500 \mathrm{C}_{16} \mathrm{H}_{32} \mathrm{O}_{2}+0,0002962963$ $\mathrm{C}_{17} \mathrm{H}_{34} \mathrm{O}_{2}+0,1025357143 \mathrm{C}_{18} \mathrm{H}_{32} \mathrm{O}_{2}+$ $0,1553191489 \mathrm{C}_{18} \mathrm{H}_{34} \mathrm{O}_{2}+0,0060283688$ $\mathrm{C}_{18} \mathrm{H}_{34} \mathrm{O}_{2}+0,0304225352 \mathrm{C}_{18} \mathrm{H}_{36} \mathrm{O}_{2}+$ $0,0005769231 \mathrm{C}_{20} \mathrm{H}_{40} \mathrm{O}_{2}+9,009067726\left(\mathrm{O}_{2}+\right.$ $\left.3,76 \mathrm{~N}_{2}\right) \Rightarrow 6,370027299 \mathrm{CO}_{2}+6,000498115$ $\mathrm{H}_{2} \mathrm{O}+33,87409465 \mathrm{~N}_{2}$

AFR stokiometri minyak jarak pagar adalah 1236,764817gram udara / 100,0000024 gram bahan bakar $=12,36764817$ gram udara $/$ gram bahan bakar.

Sedangkan untuk bahan bakar LPG, dipergunakan LPG campuran produksi PT. Pertamina yaitu terdiri atas $50 \%$ volume propane dan 50\% butane[8].Prosentase penambahan bahan bakar LPG dalam penelitian ini adalah sebesar 10\%, 20\%, 30\% dan $40 \%$ dari massa alir uap minyak jarak.

Untuk mendapatkan laju penguapan minyak jarak, maka terlebih dahulu dilakukan 
perhitungan waktu penguapan minyak jarak setiap $5 \mathrm{ml}$ pada skala yang terlihat pada ketel. Sehingga didapatkan debit penguapan sebesar $0.046 \mathrm{~mL} /$ menit. Dan untuk mendapatkan massa jenis minyak jarak yang diuapkan, maka massa minyak jarak ditimbang dan dibagi dengan volume minyak jarak pada saat mendidih, sehingga didapatkan massa jenis uap minyak jarak sebesar 0.714 gram $/ \mathrm{mL}$.

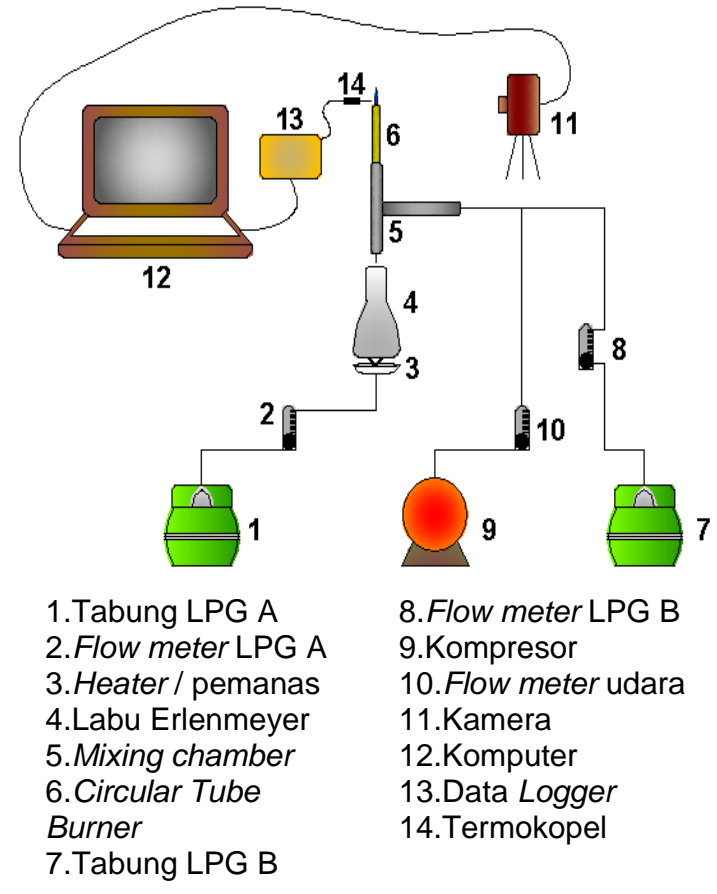

Gambar 1. Skema Alat Penelitian

Pengambilan data dan Visualisasi nyala api dilakukan pada laju penguapan minyak jarak sebesar $0.046 \mathrm{ml} / \mathrm{min}$, penambahan debit LPG sebesar $1.6 \mathrm{ml} / \mathrm{min}, 3.1 \mathrm{ml} / \mathrm{min}, 4.6 \mathrm{ml} / \mathrm{min}$ dan $6.2 \mathrm{ml} / \mathrm{min}$. Dan juga dilakukan visualisasi pembakaran premixed LPG dengan debit 15.48 $\mathrm{ml} / \mathrm{min}$. Debit udara dalam proses pembakaran divariasikan dari $0 \mathrm{ml} / \mathrm{min}$ dan dinaikkan dengan kelipatan $20 \mathrm{ml} / \mathrm{min}$ atau $5 \mathrm{ml} / \mathrm{menit}$ hingga api mengalami blow off. Untuk mendapatkan data dimensi api dan warna, digunakan kamera Canon EOS 550D. Untuk mengukur dimensi api berupa sudut dan tinggi api maka gambar yang didapatkan kemudian diolah dengan menggunakan software AutoCad 2015.
HASIL DAN PEMBAHASAN

Visualisasi nyala api

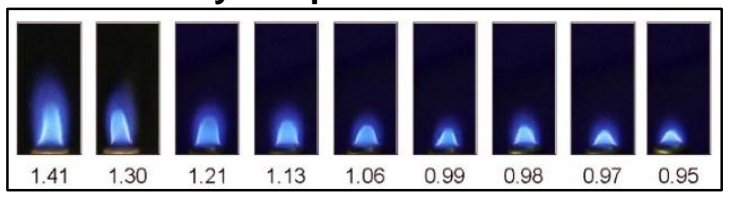

Gambar 2. Visualisasi api pada debit LPG 0\%

Dari Gambar 2 menunjukkan bahwa api dapat menyala dengan stabil pada debit udara 0 (difusi) hingga equivalence ratio 0.95 . Nyala api berwarna biru menandakan pembakaran yang terjadi mendekati stoikiometrinya dimana sebagian besar didominasi pembakaran premixed.

Pada equivalence ratio dibawah dari 1.41 seluruh bagian api berwarna biru dan terlihat dua lapis kerucut api yaitu pada kerucut dalam yang ditandai dengan nyala api berwarna biru tebal. Nyala api berwarna biru tebal merupakan nyala api premixed akibat pencampuran bahan bakar dan udara yang disuplai dari kompresor. Sedangkan nyala api biru tipis pada bagian kerucut luar merupakan pembakaran difusi dengan udara dari lingkungan sekitar api. Semakin mendekati nilai equivalence ratio 1 menyebabkan nyala api lebih terang, hal ini dikarenakan pembakaran mendekati kondisi stoikiometrinya. Kondisi api mendekati pembakaran stoikiometrinya menyebabkan bahan bakar minyak jarak terbakar sempurna dengan udara, sehingga pembakaran terbakar secara premixed yang menyebabkan api berwarna biru terang. Selain itu terlihat bahwa semakin rendah equivalence ratio tinggi api semakin pendek dan sudutnya semakin besar.

Visualisasi nyala api pada pembakaran campuran uap minyak jarak-LPG dengan berbagai prosentase LPG ditampilkan pada Gambar 3-7.

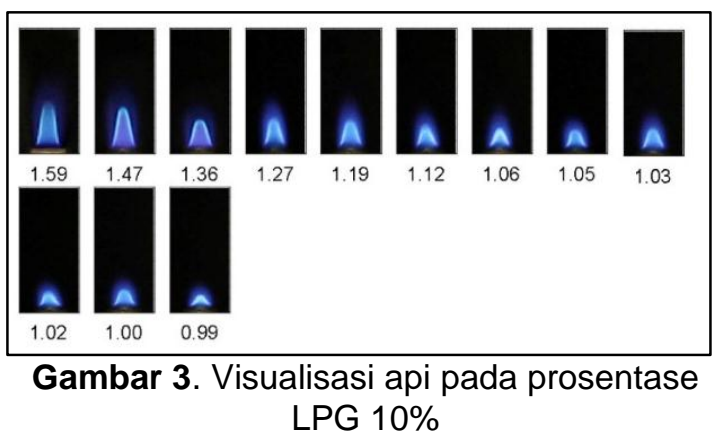




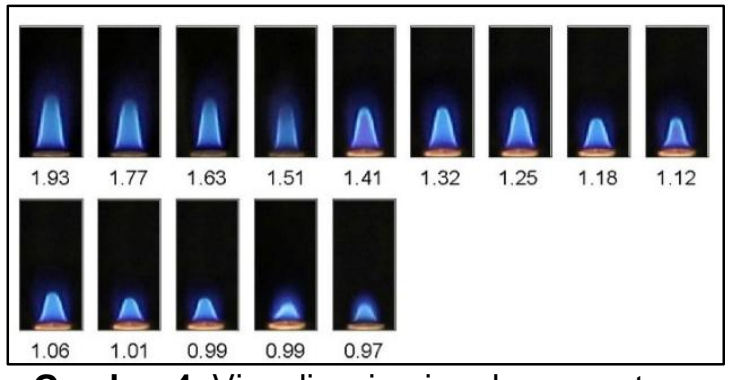

Gambar 4. Visualisasi api pada prosentase LPG $20 \%$

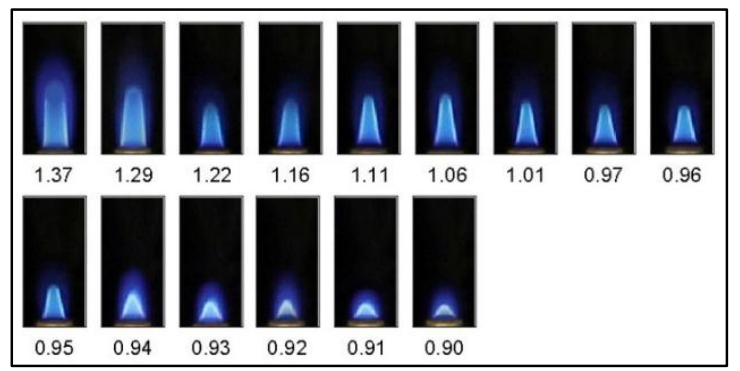

Gambar 5. Visualisasi api pada prosentase LPG $30 \%$

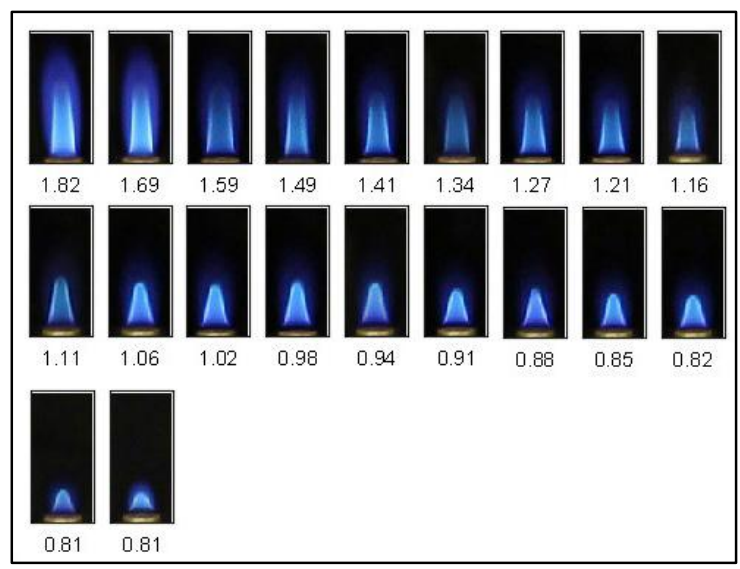

Gambar6. Visualisasi api pada prosentase LPG $40 \%$

Dari Gambar 3-7 menunjukkan bahwa pada debit bahan bakar yang konstan, jika debit udara semakin besar maka bagian api yang berwarna kuning semakin sedikit dan bagian api yang berwarna biru semakin banyak. Hal ini dikarenakan kondisi pembakaran semakin mendekati pembakaran stoikiometri $(\Phi=1)$ dan bahan bakar hampir terbakar seluruhnya secara premixed. Semakin besar prosentase LPG, bagian api yang berwarna kuning semakin sedikit, api yang berwarna kuning tidak tampak pada nilai equivalence ratio sekitar 1.8 atau lebih kecil.

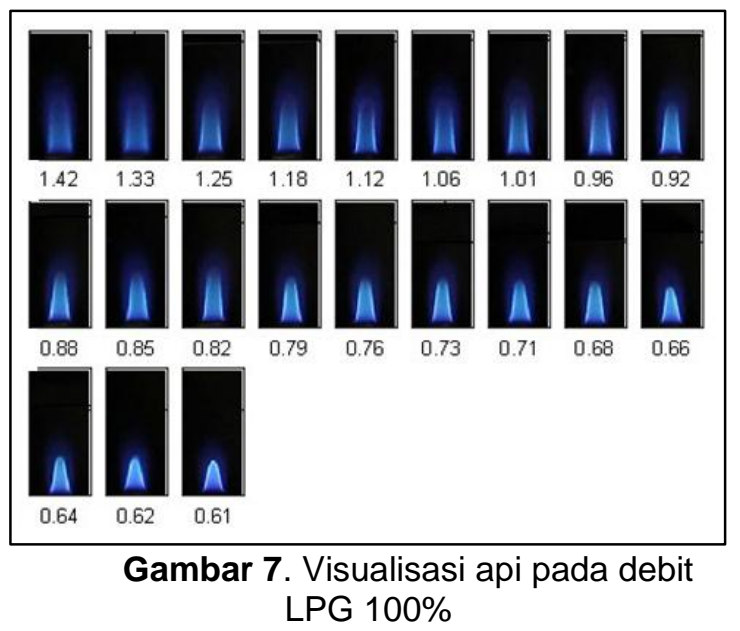

Hal ini dikarenakan LPG telah bercampur dengan uap minyak jarak pagar sehingga pembakarannya dipengaruhi oleh sebagian pembakaran LPG. Terdapat kemungkinan bahwa LPG mempunyai kecepatan berdifusi keudara yang lebih besar daripada minyak jarak, sehingga menghasilkan campuran yang lebih mendekati stoikiometri dan menghasilkan api dengan warna lebih biru. Pada equivalence ratio tertentu tampak 2 bagian kerucut api. Kerucut api bagian dalam berwarna biru terang merupakan api premixed, sedangkan kerucut api bagian luar berwarna biru tipis merupakan api difusi. Kondisi ini menunjukkan terjadinya pembakaran premixed pada mulut burner. Dari Gambar 3-7 menunjukkan bahwa semakin besar prosentase LPG, maka nyala api akan cenderung semakin stabil pada nilai equivalence ratio yang semakin kecil.

\section{Hubungan equivalence ratio terhadap kecepatan pembakaran pada berbagai prosentase LPG.}

Dari hasil visualisasi nyala api, terlihat bahwa api memiliki 2 sudut api. Seperti terlihat pada Gambar 8 :

\section{Visualisasi nyala api}

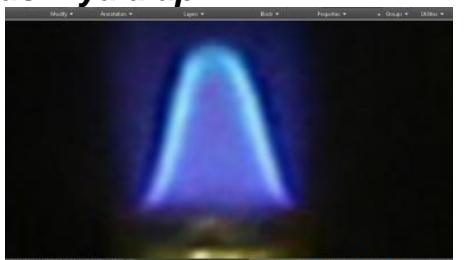

Gambar 8. Visualisasi nyala api 


\section{Pengukuran sudut}

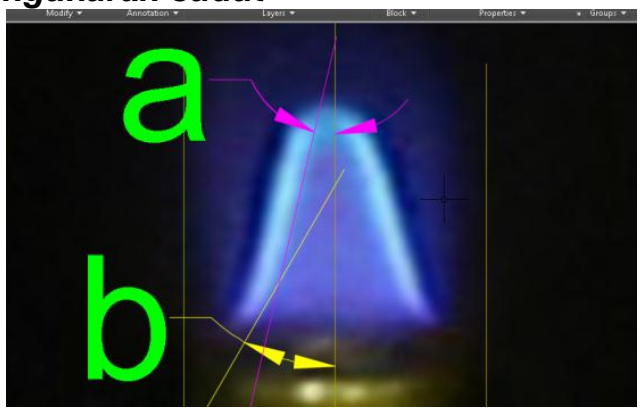

Gambar 9. Pengukuran besar sudut api

Terbentuknya 2 sudut api disebabkan oleh karena komposisi dari bahan bakar yang berubah, dengan ditambahkannya LPG ke dalam proses pembakaran. Dimana LPG itu sendiri terdiri dari 2 jenis bahan bakar yaitu propana dan butana. Dalam pembakaran premixed laminar, nilai besar sudut api mempengaruhi kecepatan pembakaran, karena nilai sudut kerucut api berbanding lurus dengan kecepatan pembakaran. Berdasarkan visualisasi foto nyala api tersebut diatas, maka didapatkan 2 grafik kecepatan pembakaran, yaitu grafik kecepatan pembakaran berdasarkan besar sudut a dan grafik kecepatan pembakaran berdasarkan besar sudut $b$. Dari hasil pengukuran besar sudut api yang terbentuk pada tiap sudut (sudut a dan sudut b), kemudian diplot dalam bentuk grafik sebagai berikut :

\section{Grafik kecepatan pembakaran berdasarkan sudut a}

Dari gambar grafik 10, terlihat bahwa untuk sudut atas, penambahan prosentase LPG akan mengakibatkan kecepatan pembakaran pada minyak jarak akan semakin menurun mendekati kecepatan pembakaran LPG. Hal ini dikarenakan sudut api yang terbentuk cenderung menurun mengikuti besar sudut api dari LPG, karena kecepatan pembakaran berbanding lurus dengan besar sudut.Seperti terlihat pada Gambar 13, besar sudut untuk masing-masing nyala api, pada $\phi \approx 1.2$ besar sudut untuk masing - masing bahan bakar minyak jarak, $10 \%, 20 \%, 30 \%$, dan $40 \%$ adalah sebesar $25^{\circ}, 14^{\circ}, 12^{\circ}, 7^{\circ}$, dan $6^{\circ}$.

Dari Gambar 10 terlihat bahwa kecepatan pembakaran uap minyak jarak pagar lebih tinggi dibandingkan dengan kecepatan pembakaran LPG. Hal ini dikarenakan pada proses pembakaran LPG, sudut api yang terbentuk lebih kecil daripada sudut api yang terbentuk pada pembakaran uap minyak jarak murni pada equivalence ratio yang sama. Sehingga meskipun nilai kecepatan reaktan dari pembakaran LPG juga lebih besar dibanding dengan kecepatan reaktan uap minyak jarak pada equivalence ratio yang sama. Misalkan pada equivalence ratio 1.06 . Terlihat bahwa besar sudut api dan kecepatan reaktan pada pembakaran uap minyak jarak sebesar $27^{\circ}$ dan $75.5 \mathrm{~cm} /$ detik. Sedangkan pada pembakaran LPG murni adalah sebesar $7^{\circ}$ dan 98.01 $\mathrm{cm} /$ detik.

Kecepatan pembakaran campuran uap minyak jarak dengan LPG memiliki nilai yang lebih rendah dibandingkan dengan kecepatan pembakaran uap minyak jarak pagar murni. Ini dikarenakan besar sudut api pada pembakaran uap minyak jarak pagar dengan penambahan berbagai prosentase LPG cenderung lebih kecil dibandingkan dengan sudut api pada pembakaran uap minyak jarak.

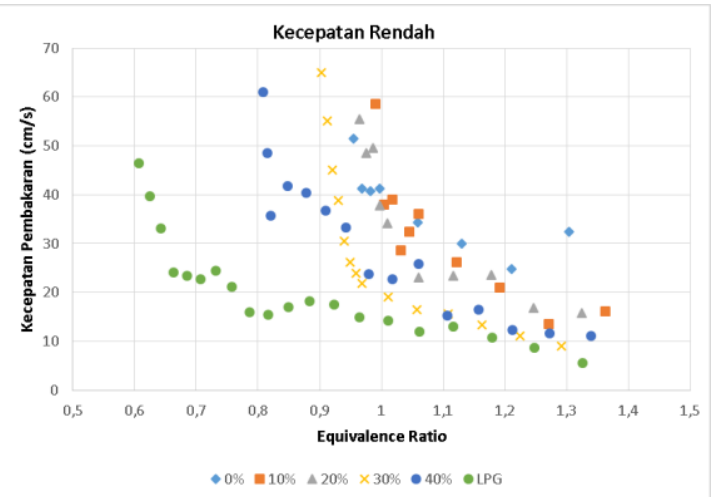

Gambar 10. Grafik hubungan kecepatan pembakaran dengan equivalence ratio berdasarkan besar sudut atas untuk berbagai variasi prosentase LPG.

\section{Grafik kecepatan pembakaran berdasarkan sudut b}

Pada besar sudut bawah, penambahan prosentase LPG akan mengakibatkan sudut api yang terbentuk cenderung semakin bertambah seperti terlihat pada Gambar 11. Dari grafik terlihat bahwa semakin besar prosentase penambahan bahan bakar LPG, maka kecepatan pembakaran semakin besar pada equivalence ratio yang sama. Karena sudut api yang terbentuk pada tiap penambahan 
prosentase bahan bakar semakin besar pada equivalence ratio yang sama. Misalkan pada equivalence ratio 1.2 terlihat besar sudut api untuk masing-masing prosentase yaitu $0 \%$ atau minyak jarak murni, 10\%, 20\%, 30\% dan $40 \%$ berturut-turut adalah sebesar $25^{\circ}, 28^{\circ}, 32^{\circ}, 33^{\circ}$ dan $40^{\circ}$. Nilai sudut api yang semakin besar maka akan mengakibatkan kecepatan pembakaran juga meningkat, karena nilai sudut kerucut api berbanding lurus dengan kecepatan pembakaran (SL). Selain itu penambahan bahan bakar juga akan mengakibatkan kecepatan reaktan akan meningkat sehingga nilai kecepatan pembakaran juga akan semakin meningkat.

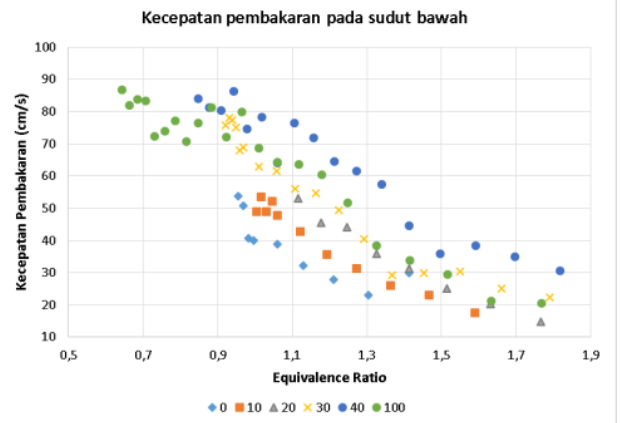

Gambar 11. Grafik hubungan kecepatan pembakaran dengan equivalence ratio berdasarkan besar sudut bawah untuk berbagai variasi prosentase LPG.
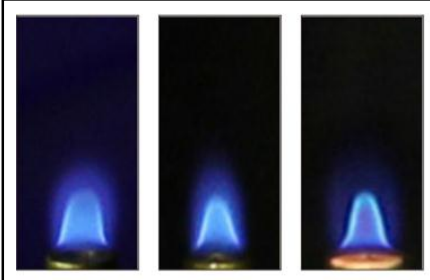

$20 \%$

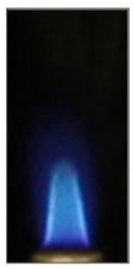

$30 \%$

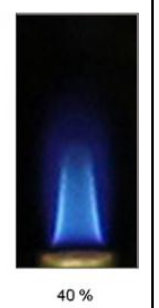

Gambar 12. Visualisasi api pada equivalence ratio 1,2 untuk berbagai variasi prosentase LPG.

Dari Gambar 11 juga terlihat bahwa kecepatan pembakaran uap minyak jarak pagar lebih rendah daripada kecepatan pembakaran LPG. Ini dikarenakan pada proses pembakaran LPG, sudut api yang terbentuk lebih besar daripada sudut api yang terbentuk pada pembakaran uap minyak jarak murni pada equivalence ratio yang sama. Selain itu, nilai kecepatan reaktan dari pembakaran LPG juga lebih besar dibanding dengan kecepatan reaktan uap minyak jarak pada equivalence ratio yang sama. Misalkan pada equivalence ratio 1.06. Terlihat bahwa besar sudut api dan kecepatan reaktan pada pembakaran uap minyak jarak sebesar $31^{\circ}$ dan $75.5 \mathrm{~cm} /$ detik. Sedangkan pada pembakaran LPG murni adalah sebesar $41^{\circ}$ dan $98,01 \mathrm{~cm} /$ detik.

Kecepatan pembakaran campuran uap minyak jarak dan LPG memiliki nilai yang lebih besar dibandingkan dengan kecepatan pembakaran uap minyak jarak pagar murni. Ini dikarenakan besar sudut api dan kecepatan reaktan pada pembakaran uap minyak jarak pagar dengan penambahan berbagai prosentase LPG cenderung lebih besar dibandingkan dengan sudut api dan kecepatan reaktan pada pembakaran uap minyak jarak.

Didapatkan bahwa semakin besar equivalence ratio maka kecepatan pembakarannya akan turun. Hal ini disebabkan karena semakin sedikitnya udara yang tersedia untuk membakar bahan bakar pada kondisi kaya sehingga sudut api cenderung lebih kecil dan kecepatan reaktannya rendah.

\section{KESIMPULAN}

Dari hasil pengamatan dan analisis datadata yang diperoleh dalam penelitian maka dapat disimpulkan beberapa hal sebagai berikut :

1. Penambahan bahan bakar LPG pada uap minyak jarak mengakibatkan terbentuknya 2 sudut api.

2. Pada sudut atas, kecepatan pembakaran semakin menurun seiring dengan penambahan prosentase LPG. Sedangkan pada sudut bawah, kecepatan pembakaran semakin meningkat seiring dengan penambahan prosentase LPG.

3. Semakin besar prosentase LPG, maka nyala api cenderung semakin stabil pada nilai equivalence ratio yang semakin kecil.

\section{DAFTAR PUSTAKA}

[1] Wardana I.N.G.,2008. Bahan Bakar dan Teknologi Pembakaran. PT. Danar Wijaya, Brawijaya University Press.

[2] Yokoyama, S. 2008. The Asian Biomass Handbook : A Guide for Biomass Production and Utilization, The Japan Institute of Energi. 
[3] Baukal, C. E. Jr. 2013. The John Zink [6] Wirawan I. K. G., 2014. Pembakaran Hamworthy : Combustion Handbook, Second Edition, CRC Press 6000 Broken Sound Parkway NW, Suite 300 Boca Raton, FL 33487-2742.

[4] Saroso H., Wardana I. N. G., Soenoko R., Hamidi N., 2014.Premixed combustion of coconut oil in a hele-shaw cell, International Journal of Renewable Energy Development Premixed Minyak Nabati Pada Perforated Burner, Brawijaya Malang.

[7] Wardana I.N.G.,2008. Bahan Bakar dan Teknologi Pembakaran. PT. Danar Wijaya, Brawijaya University Press.

[8] www.tenderoffer.biz., LPG - Composition, Based Specification and Standard Safety. 3 (3) 155-160.

[5] Wirawan, I. K. G., Wardana I. N. G., Soenoko R., Wahyudi S., 2014.Premixed Combustion of Kapok (ceiba pentandra) seed oil on Perforated Burner, International Journal of Renewable Energy Development 3 (2), $91-97$. 